\title{
EXPRESSION OF TECHNICAL CREATIVITY AT PRIMARY SCHOOL STUDENTS
}

\author{
Dragica Pešaković \\ OŠ Destrnik - Trnovska vas, Destrnik, Slovenia \\ E-mail: dragica.pesakovic@guest.arnes.si
}

\begin{abstract}
Subjects such as design and technology are in Slovenian primary schools based on students' creativity and discovery and consequently by preparing students to participate in the technical field. As we know, the creative ability is a spontaneity of expression and other creative skills, which can be motivated or hindered by the teachers. Through testing we can get to the image of the actual state of the creative abilities of students. Therefore, a special instrumentation and methodology were developed, which could achieve that the test conditions were equal for all participants.

The purpose of this study was to examine the state-level of technical creative skills of students with the help of a modelled test of creativity. In the verbal part we valued the originality, flexibility and fluency. In non-verbal part we valued originality, flexibility and elaboration. Each element of technical creativity was evaluated through a detailed criterion and benchmark points. The results, which will be presented in the article confirms that students who express a higher level of creativity are more effective in learning. The survey shows that the creativity of students depends on a number of factors, including sex - girls are more creative than boys, and from age - older people are more creative. Students expressed a low level of overall creativity. We can speak about creativity expressed specifically in this test, which can serve for comparison purposes only, not to describe the overall situation. There can be many reasons, but this can already be the subject of other research and another following study.
\end{abstract}

Key words: basic education, creativity, engineering and technology, engineering creativity.

\section{Introduction}

Between the needs of which inspired the renovation of the education system in the entire vertical, the creativity and innovation, openness to change and ability to apply knowledge in new and unpredictable situations have to be mentioned as well. Documents that were created during the curricular reform sort creative individuals among core values and encourage creativity between the principles and objectives of education at all levels. Openness and a better procedural and developmental orientation of curriculum for schools, implies a greater autonomy and accountability, as well as good technical skills and creativity for teachers. On the basis of general principles, objectives and guidelines, each teacher has to approach to designing the curriculum creatively - at planning, implementing and evaluating educational work in the department.

For teachers in Europe creativity is a fundamental skill. The European Commission presented the results of early studies on creativity and innovation in schools. These show that 94 percent of teachers in Europe believe that creativity is a fundamental skill. 88 percent of them expressed the belief that each individual can be creative. The results of the study also showed that 95.5 percent, according to teachers' creativity, can be applied to all areas of knowledge and at each school subject. They also argued that creativity is not only significant in subjects that are inherently creative, such as art, music or technology. An important part of the creative learning is also the curiosity, analytical skills and imagination to address a critical and strategic thinking (Vladni portal, 2009). 
PROBLEMS

OF EDUCATION

IN THE $21^{\text {st }}$ CENTURY

Volume 46, 2012

102

\section{The Definition of the Problem}

Pečjak (1987) points out that a fundamental aspect in the study of creativity is the originality. Creative response is always and necessarily unique, which means that it must give something new, peculiar, rare or even something non - recurring. He says that creating the opposite state of preservation is by its changing and breaking, and thus in a sense, aggressive and violent to reality. It must exceed a given frame to accomplish the originality (Likar, p. 9). Most people are caught in rigid ways of thinking. Solutions, which they hold to, make them unaware of the other, better, more original one. One of the factors that affect the rigidity of thought is experience. Creativity is a question of contention in the psychological discussions. Trstenjak (Pečjak 1987) believes that creativity cannot be measured. (Guilford, Torrance, Barron, Kvaščev etc.). Guilford believed that divergent ability was closely connected to creative thinking (Jaušovec 1987). Therefore, many psychologists have renamed their tests of divergent abilities into tests of creativity. This is considered by many other psychologists as an inappropriate and too narrow conception, since the scope of creativity is much bigger and it does not contain only divergent abilities. According to Žagar (1992), the necessity for creative achievements is also convergent thinking and specific personality traits. But Trstenjak has come to the conclusion that creativity cannot be measured. However, Pečjakhas a different opinion (1987). He gives priority to solving of the problems and not to their opening. But the conditions of divergent thinking must be satisfied, as well as multiple solutions or responses. Such is, for example, the Hargreave's test of unfinished pictures, the test of photo titles or stories, the test of visible symbols, the test of picture stories and similar. He is certain that each individual is in daily life limited to certain frames, not only in tests (Pečjak, 1987: 123).

Kvaščev (Jurman 2004) suggests four ways of measuring the creativity: by using the creativity tests, by using individual's personal characteristics, by assessing the individual's creativity and by evaluating the final product. The test of creativity is characterized by logic, which is opposite to the logic of intelligence tests, where there is only one solution or response and no possibility of disconformism in thought. The answers are often adapted to the dominant culture or environment in which the compiler of the tasks is. Therefore, we could say that intelligence tests measure the practical adaptation of the individual to the environment (Pečjak 1987). Guilford (Jaušovec in 1987) was the one who broke the tradition of tests of intelligence, when he split it into convergent and divergent thinking. The first is expressed in resolving of closed problems, allowing only one solution. The other is reflected in resolving outstanding problems, which can be solved in different ways and allow more than one possible solution. To measure the divergent abilities Guilford (1971, Jaušovec 1987) has assembled a completely new tests, which include factors of divergent thinking. The factor analysis of divergent thinking revealed that it contains three large dimensions: fluency, flexibility and originality, sophistication, elaboration and the ability to detect problems.

Creativity tests usually contain a small number of tasks that are set as individual problems. These problems include: the problem of unfinished material, the problem of inventing the titles, the problem of transforming the material, the problem of association, the problem of sensitivity, understanding the implications of the problem, the problem of hidden figures, the problem of creating words, the problem of unusual ideas - the individual deals with a story that contains a problem and he shall describe causes that explain the problem, the problem of unstructured material and the problem of vague images or outlines. Tests of creativity are characterized by the need to be as open as possible and that each individual has as much freedom as possible and is not limited in time (Jurman, 2004: 132).

Measurement of creativity refers to the direct estimation of individual creativity. The area of such measurement of creativity is limited primarily to the school situation, where pupil's creative behaviour is estimated by all his teachers or classmates. The measurement usually takes 
place by a specific method, namely, when the teachers or students are required to determine the student who, in their opinion, is the most creative in the classroom community (Jurman, 2004). The assessments of students are much more reliable than the assessment of teachers, as students perceive each other differently. Teachers on the other hand, are much more tied to the school situation when assessing creativity (MarentičPožarnik, 2003). The assessors can also be parents or friends who rate the child's creative potential (Jaušovec 1987). The main problem with this kind of evaluation is the diversity of situations in which people are observed and therefore differently assessed. Since creativity is a very broad term, every student can see the area of creativity differently. Therefore, it is very important that the concept of assessment is for assessors determined precisely and unequivocally (Pečjak 1987, Jurman 2004).

Based on indicators of creativity there have already been set in the past some characteristics of creative individuals (Claxton, Edwards, Scale-Constantinou, 2006). Claxton (2006) points out six indicators, Guilford (1968), who has worked together with Lowenfeld, has pointed out eight indicators, which should help in identifying the presence and level of creativity of the individuals (Belamarić, Supek, 1987), as follows: sensitivity to problems, receptivity, flexibility, originality, ability of analysis and abstraction, the ability of transformation (redefinition), synthesis and coherent organization.

Torrance (1974, Jurman 2004, Pečjak 1987, Jaušovec 1987) has solved this problem by using the following questions that relate to various aspects of creative thinking:

- Who in the class has the most ideas? (Fluency),

- Who in the class has original and unusual ideas? (Originality),

- Who is the first to find a new solution if the situation suddenly changes? (Flexibility),

- Who is the one, who provides the most detailed solution when a problem occurs? (Elaboration).

Assessments of creativity have better metric characteristics, if we use well-established scales, either numeric, graphic or descriptive (Pečjak, 1987). Assessment of creativity has one big advantage over testing. The assessor is available to the data obtained in a natural situation (school, family, work), while the experimental data is obtained in artificial situations. The assessor has more experience with the individual who is being assessed, which may be taken as a disadvantage, since it gives a rise to a number of subjective errors (hallo effect, a logical error and personal equation) (Pečjak, 1987; Jurman, 2004;MarentičPožarnik, 2003) .

\section{Characteristics of Technical Creativity}

According to Duh, the artistic creativity can be defined in the same way as Art, "but we should add it some specific elements of art, such as art - expressive means" (Duh 2004: 22). The same can be said for Technique and technology, to which we should add some technical means of expression. Technique and technology in primary schools is based on the detection of student's creativity, channelling spontaneous student's technical development, identifying specific technical expression, thus preparing students to participate in the technical field. As we know, the creative ability is equally distributed among individuals, therefore it reflects the impact the others have on it; especially the impact of teachers on students. It is sometimes inspiring but often obstructing the development of children's imagination, spontaneity of expression and other creative skills. To get the image of the actual state of the creative abilities of students, we can get it by testing pupils, whereas all test conditions have to be equal for all participants, as well as evaluation of their products.

In the field of technique and technology, a suitable definition derives from an individual achievement and seeks to be established as something new (Aberšek, 2012). A creative person 
PROBLEMS

OF EDUCATION

IN THE $21^{\text {st }}$ CENTURY

Volume 46, 2012

104

is someone who has resolved a problem in such a way that he did not recall the solution from the memory but he created it for this newly occurred problem (Jaušovec, 1987). Students in the classroom learn how the natural laws are used in technique and technology. Therefore, they discover and learn about simple technical and technological problems and by using simple tools they are looking for ways to solve them. In such a way they are creatively linking science and technical knowledge to practice. Technique and technology is a school subject that implements the symbolic level to reality. When making objects and building construction, the students have the opportunity to develop their skills to find and create new solutions, creativity and make decisions (Curriculum for Technique and Technology, 2011).

\section{Methodology of Research}

In the exploration of creativity in the past, much research has been made on the behalf of experts from various fields. They tried to define its basic characteristics (Craft, 2006), to highlight the various incentive and hampering factors in its development (Jeffrey, 2001; Craft, 2006) and to determine its domain in some areas (Leach, 2001). Basic orientation of research creativity was its placement in the context of socio-psychological framework, where an organized method of teaching includes the development of individual creativity. In the nineties, the researchers focused on the creativity of all students in the classroom rather than on individual's potential.

The purpose of this research is to examine the state-level of technical and creative skills of students in the 7th and 9th grade, their capacity for creative and common factors, the level of technical creativity, which will be determined in keeping with the six factors of creativity, such as (originality, flexibility, sensitivity to technical problems, technical re-definition, fluency and elaboration. Each element of technical creativity will be followed through specific tasks and scored with the help of established scale.

The study uses a method of causal non-experimental educational research. The sample includes 168 students of the 7th and 168 9th grade. The testing of students was done in the classroom at Technique and technology. The students were tested with the modeled assay of technical creativity which was built with the help of Torrance's test of creative thinking. The test consists of two drawings, in which a student shows various elements of his own technical abilities of expression. The first task is based on the verbal part, in which the student should write as many uses of the gear drives as possible. For the non-verbal part, the student must complete an unfinished picture. The time is limited, in our case to 45 minutes. All students were tested in appropriate experimental conditions.

\section{Results of Research}

The data were processed automatically by the program for statistical data processing SPSS 17.0, on the level of descriptive and inferential statistics. The following procedures have been used:

- Frequency distribution (f, $\mathrm{f} \%$ ) of descriptive variables (gender, class, final score) ;

- $\chi^{2}$ - test of the hypothesis of independence to define relationships between variables (technical creativity regarding gender, class and final assessment at Technique and Technology). 
Table 1. The achievements of students in verbal and non- verbal test of technical creativity.

\begin{tabular}{|c|c|c|c|c|}
\hline & \multicolumn{2}{|c|}{ The stage of verbal creativity } & \multicolumn{2}{c|}{ The stage of non - verbal creativity } \\
\hline The stage general creativity & $\mathrm{f}$ & $\mathrm{f} \%$ & $\mathrm{f}$ & $\mathrm{f} \%$ \\
\hline Unexpressed (0 points) & 6 & 1.8 & 24 & 7.1 \\
\hline Low (1-3 points) & 186 & 55.3 & 222 & 66.1 \\
\hline Middle (4-6 points) & 126 & 37.5 & 54 & 16.1 \\
\hline High (7-9 points) & 18 & 5.4 & 36 & 10.7 \\
\hline Total & 336 & 100 & 336 & 100 \\
\hline
\end{tabular}

It was assumed that the difference between verbal and nonverbal work would be bigger, because these are only two different kinds of tasks. But it turned out that we have already balanced the test of creativity by criteria itself, so both parts have been equivalent in comparison to global results. Namely, each student could gain a maximum of 3 points for each component, so there has been little loss for students with extreme results at the individual component. A comparison of various shapes and components were necessary, in addition, such extreme cases were rare and wouldn't significantly affect the result (Table 1).

\section{Gender Differences}

Sex differences at the level of technical creativity are statistically significant $\left(\chi^{2}=8.491\right)$ which confirms the fact that the girls in the test of technical creativity have scored higher than boys. The results show (Table 2) that the percentage of girls in the middle and high level of creativity $(58.3 \%)$ is higher than the percentage of boys $(43.8 \%)$. The girls have proved more technical creativity in the verbal area, which showed a greater degree of flexibility, fluency, and elaboration.

Table 2. General technical creativity concerning gender.

\begin{tabular}{|c|c|c|c|c|c|c|}
\hline & \multicolumn{2}{|c|}{$F$} & \multicolumn{2}{c|}{ M } & \multicolumn{2}{c|}{ Total } \\
\hline $\begin{array}{c}\text { The stage of general } \\
\text { creativity }\end{array}$ & $f$ & $f \%$ & $f$ & $f \%$ & $f$ & $f \%$ \\
\hline Unexpressed (0 points) & 0 & 0 & 0 & 0 & 0 & 0 \\
\hline Low (1-3 points) & 60 & 41.6 & 108 & 56.2 & 168 & 50 \\
\hline Middle (4-6 points) & 66 & 45.8 & 72 & 37.5 & 138 & 41.1 \\
\hline High (7-9 points) & 18 & 12.5 & 12 & 6.3 & 30 & 8.9 \\
\hline Total & 144 & 100 & 192 & 100 & 336 & 100 \\
\hline & & \multicolumn{7}{c|}{$\chi^{2}=8,491$} & & \\
\hline
\end{tabular}


PROBLEMS

OF EDUCATION

IN THE $21^{\text {st }}$ CENTURY

Volume 46, 2012

Dependence of the Technical Creativity on the Assessment at Technique and Technology

Table 3. General creativity concerning the final assessment at Technique and technology.

\begin{tabular}{|c|c|c|c|c|c|c|c|c|c|c|}
\hline & \multicolumn{2}{|c|}{2} & \multicolumn{2}{|c|}{3} & \multicolumn{2}{c|}{4} & \multicolumn{2}{c|}{5} & \multicolumn{2}{c|}{ Total } \\
\hline $\begin{array}{c}\text { The stage of general } \\
\text { creativity }\end{array}$ & $f$ & $f \%$ & $f$ & $f \%$ & $f$ & $f \%$ & $f$ & $f \%$ & $f$ & $f \%$ \\
\hline \begin{tabular}{c} 
Unexpressed (0 points) \\
\hline Low (1-3 points)
\end{tabular} & 0 & 0 & 0 & 0 & 0 & 0 & 0 & 0 & 0 & 0 \\
\hline Middle (4-6 points) & 0 & 0 & 0 & 0 & 42 & 12.5 & 96 & 28.6 & 138 & 41.1 \\
\hline High (7-9 points) & 0 & 0 & 0 & 0 & 6 & 1.8 & 24 & 7.1 & 30 & 8.9 \\
\hline Total & 0 & 0 & & 5.4 & 156 & 46.4 & 162 & 48.2 & 336 & 100 \\
\hline
\end{tabular}

Differences in the assessment at Technique and technology and the level of technical creativity are statistically significant $\left(\chi^{2}=79,767\right)$, which confirms the fact that the students with a medium level of expressed creativity have excellent grades $(28.6 \%)$, half with very good $(12.5 \%)$ and no student with good or adequate assessment. Among the highly creative students are mostly the ones whose assessment is excellent (7.1\%). Students, who expressed a higher level of creativity, are also better academic achievers (Table 3).

\section{Technical Creativity vs. the Age of the Student}

It has been verified if the age of the students has any influence on degree of creativity. The results are shown in table 4.

Table 4. General creativity concerning the whole class.

\begin{tabular}{|c|c|c|c|c|c|c|}
\hline & \multicolumn{2}{|c|}{ 7th grade } & \multicolumn{2}{c|}{ 9th grade } & \multicolumn{2}{c|}{ Total } \\
\hline The stage of general creativity & $\mathrm{f}$ & $\mathrm{f} \%$ & $\mathrm{f}$ & $\mathrm{f} \%$ & $\mathrm{f}$ & $\mathrm{f} \%$ \\
\hline Unexpressed (0 points) & 0 & 0 & 0 & 0 & 0 & 0 \\
\hline Low (1-3 points) & 102 & 60.7 & 66 & 39.3 & 168 & 50 \\
\hline Middle (4-6 points) & 54 & 32.2 & 84 & 50.0 & 138 & 41.1 \\
\hline High (7-9 points) & 12 & 7.1 & 18 & 10.7 & 30 & 8.9 \\
\hline Total & 168 & 100 & 168 & 100 & 336 & 100 \\
\hline \multicolumn{7}{|l|}{$\chi^{2}=15,436$} \\
\hline
\end{tabular}

Differences in the age and level of technical creativity are statistically significant $\left(\chi^{2}=\right.$ $15,436)$. Percentage of pupils with meddle and high level of creativity is higher in the $9^{\text {th }}$ grade $(50+10,7=60.7 \%)$ than in the $7^{\text {th }}$ grade $(39.3 \%)$ according to table 4 . It is confirmed that the level of technical creativity increases with the age of the student. 


\section{Discussion}

It turned out that the students have achieved mainly low level of creativity at this mediated test, as well as in general, verbal and non- verbal work. They showed low fluency and originality, unexpressed elaboration and medium level of flexibility. Results previously obtained attributed to the incomplete process in comparison to the actual situation. We believe in a higher level of creativity of students, as they were expressed by a given test of creativity. Causes are seen in the following points:

To achieve a creative product, in our opinion, it is very important to have inspiration, but it is difficult to lure the students into a situation that is not good for creativity. Inspiration does occur "spontaneously", it occurs suddenly and unexpectedly, something which in my case it was not.Essential for creativity is also motivation. We must recognize that this presented a lot of trouble to me, especially with the students of the ninth grade. Above all, boys were generally very uninterested in solving problems, but this does not mean that they are uncreative, just currently uncooperative, the task seemed tedious to them, even "childish". Perhaps the reason for the low results is too strict criteria, although they were only determined after a review of all our products and the criterion for creating the entire class of students. Since expectations were high and students could be in general more creative, the criteria were high.

Learning success is dependent on the individual's creativity. The girls have expressed a higher level of verbal part and hence the overall creativity. On the non - verbal part there were no differences according to gender. Creativity is also dependent on the age of the pupil. It is a complex phenomenon, which makes it difficult to measure. This was confirmed by numerous studies in the world (Ai, 1999). It was found that the creativity of children is decreasing. The reason is the amount of time the children spend watching TV, playing computer games rather to be engaged in creative activities. Even in schools there is not enough support to develop it, although 2009 was the year of European creativity. As a result, it occurred the period of crisis of creativity (Bronson, Merryman, 2010).

\section{Conclusion}

With the obtained results and statistical analysis it has been demonstrated that technical creativity is not only dependent on gender, age but also on evaluation at Technique and Technology. Students have demonstrated a low level of technical creativity, both verbally and non-verbally. The expressed creativity in this test, can serve only for comparison and not to describe the overall situation. There can be many reasons, but this will be the subject in the following research study.

Technical factors, which are complementary to each other, have a higher degree of integration. In practice this means that the development of any factor indirectly develops creativity and hence encourages all others. As the students in the class respond differently to teacher's impulses and creative technical work, the teacher has to operate in such a way that the students activate various factors of technical creativity. Only with such an operation can be expected to raise the creativity entirety. It would be interesting to compare the results of this study, which focused exclusively on the territory of Slovenia with similar studies conducted outside its borders and to find possible similarities and differences. 
PROBLEMS

OF EDUCATION

IN THE $21^{\text {st }}$ CENTURY

Volume 46, 2012

108

\section{References}

Aberšek, B. (2012). Didaktika tehniškega izobraževanja med teorijo in prakso, Ljubljana, Zavod Republike Slovenije za šolstvo.

Ai, X. (1999). Creativity and Academic Achievement: An Investigation of Gender Differences. Creativity Research Journal, 12 (4), 329-337.

Belamarić, D., Supek (1987). Djete i kreativnost. Globus, Zagreb.

Čagran, B., Bratina, T. (2010). Uvod v metodologijo pedagoškega raziskovanja. UM: Pedagoška fakulteta.

Claxton, G., Edwards, L., Scale-Contantinou, V. (2006). Cultivating creative mentalities: A framework for education; v: Wegerif, R., Craft, A. (ur.) Thinking Skills and Creativity. Vol. 1, št. 1, Str. 57-61.

Craft, A. (1997). Identity and creativity: education for post-modernism? Teacher Development: International Journal of Teacher' Professional Development, 1 (1), 83-96.

Craft, A. (2006). Creativity in Schools; v: Jackson, Oliver, Shaw, Wisdom (ur.) Developing Creativity in Higher Education. Routledge, New York, London.

Duh, M. (2004). Vrednotenje kot didaktični problem pri likovni vzgoji. Maribor: Pedagoška fakulteta.

Guilford, J. P. (1968). Osnove psihološke i pedagoške statistike. Savremena administracija, Beograd.

Jauševec, N. (1987). Spodbujanje otrokove ustvarjalnosti: Priročnik za učitelje, študente in starše. Ljubljana. Državna založba Slovenije.

Jeffrey, B., Liebling, M. (ur.). Creativity in Education. Continuum, London.

Jurman, B. (2004). Inteligentnost, ustvarjalnost, nadarjenost. Ljubljana: Center za psihologijo.

Kvaščev, R. (1976). Psihologija stvaralaštva. Beograd: Beogradsko izdavačko grafički zavod.

Leach, J. (2001). A Hundred possibilities: creativity, community and ICT. v: Craft, A.,

Likar, B, idr. (2010). Ustvarjalnost, podjetnost, inovativnost. Ljubljana. Gradivo za izvajanje projekta UPI.Javna agencija RS za podjetništvo in tuje investicije.

Lowenfeld, V., Brittain, W.L. (1964). Creative and Mental Growth. The Macmillan Company, New York.

Marentič-Požarnik, B. (2003). Psihologija učenja in pouka. Ljubljana: DZS.

Pečjak, V. (1987). Misliti, delati, živeti ustvarjalno. Ljubljana: DZS.

Torrance, P. (1981). Kreativnost.Pedagogija. Časopis saveza pedagoških društava Jugoslavije.

Trstenjak, A. (1981). Psihologija ustvarjalnosti. Ljubljana: Slovenska Matica.

Učni načrt Tehnika in tehnologija. (2011). Ljubljana: Zavod RS zašolstvo.

Vladni portal (2009).Pridobljeno 3/1/2012 s spletne strani http:/www.evropa.gov.si/si/vsebina/novica/ news/za-ucitelje-v-evropi-ustvarjalnost-temeljna-vescina/026caeb725/).

Žagar, D. (1992). Ustvarjalnost. Ljubljana: Zavod Republike Slovenije za šolstvo.

Advised by Laima Railienè, University of Siauliai, Lithuania

Received: May 16, 2012

Accepted: August 22, 2012

Dragica Pešaković $\quad$ OŠ Destrnik - Trnovska vas, Destrnik, Slovenia.

E-mail: dragica.pesakovic@guest.arnes.si 